\title{
Devlet İdaresiyle İlgili Konularda Hanefî Fıkıh Literatüründeki Hükümlerle Ebu Hanife'nin İktidara Yönelik Tavrı Arasındaki Farklılık
}

\section{Ahmet AYDIN}

Öz: Bu makalede, Ebu Hanife'nin devlet idaresine karşı tutum ve davranışlarıyla Hanefî eserlerde devlet yönetimiyle ilgili konularda yer alan hükümler arasında farklılık bulunduğu tezi savunulmaktadır. Ebu Hanife Emevi ve Abbasi dönemlerinde yaşamış ve her iki devlet idaresinin kendisine teklif ettiği görevleri kabul etmemiş, bu nedenle baskı ve işkence görmüş, hapse atılmış hatta bu baskılar onun ölümüne sebebiyet vermiştir. Ebu Hanife'nin bu tutumuyla devlet idaresine karşı muhalif bir konumda yer aldığı, en azından yönetimlerin yanında yer almak istemediği anlaşılmaktadır. Diğer taraftan, Hanefi mezhebinde devlet başkanına önemli yetkiler tanındığı ve birçok hususun onun iznine bağlandığı görülmektedir. İlgili konularda diğer mezheplerin hükümleri dikkate alındığında Hanefiler' in en uç konumda bulunduğu anlaşılmakta, bu durum devlet başkanlarının ısrarlı görev tekliflerini kabul etmeyip işkence gören Ebu Hanife'nin tutumuyla, kanaatimizce, farklılık arz etmektedir. Makalede bu farklılık analiz edilecektir.

Anahtar Kelimeler: Ebu Hanife, Devlet Yönetimi, Hüküm, Hanefi Literatürü

\section{Difference Between the Legal Provisions in the Hanafi Fiqh Literature on the Issues Related to the State Government and the Abu Hanifa's Attitude towards Power}

Abstract: In this article, we support the thesis that there is a difference between the attitudes and behaviors of Abu Hanifa towards the state government and the legal provisions related to state administration in Hanafi works. Abu Hanifa lived during the Umayyad and Abbasid periods and did not accept the duties offered by both state administrations, so he was subjected to pressure and torture, imprisoned and even these pressures caused his death. It is understood that with this attitude of Abu Hanifa, he was in an opposing position against the state administration, at least he did not want to be with the administrations. On the other hand, it is seen that in the Hanafi school, the head of state was given important powers and many issues were subject to his permission. Considering the provisions of other Islamic law school on the related issues, it is understood that the Hanafis are at the extreme position, which, in our opinion, differs with the attitude of Abu Hanife, who has been tortured by not accepting the insistent duty offers of the heads of state. This difference will be analyzed in the article.

Keywords: Abu Hanifa, Government Administration, Legal Provisions, Hanafi Literature 


\section{Giriş}

Ebu Hanife, İmâm-ı Âzam (en büyük lider) sıfatıyla anılan bir mezhep önderidir. Vefat ettiğinde kendisine işkence yapan Halife Ebu Cafer el-Mansur'un (ö. 158) dahi cenazesine iştirak etmesi ${ }^{1}$, onun halk nezdindeki itibarını göstermesi açısından önemlidir. Ebu Hanife'nin (ö. 150) Müslümanlar tarafından bir mezhep önderi kabul edilmesinin, halk indinde bu derece otorite ve itibar kazanmasının arka planında bazı hususların etkili olduğu ileri sürülebilir.

Yaptığımız bir araştırmada Ebu Hanife'nin İslam toplumunda otorite ve itibar kazanmasında, kamu görevi kabul etmemesi, devlet yöneticilerinin baskılarına sonuna kadar direnmesi, halkın sempati duyduğu Hz. Ali evladıyla iyi ilişkiler içinde olması, zamanla yöneticilerin kendisine iade-i itibarda bulunmaları gibi bazı unsurların etkili olduğu neticesine ulaşılmıştır. ${ }^{2}$ Tarafımızdan tespit edilen bu gerekçeler arasında özellikle onun kamu görevi almaması, makalemiz açısından önemlidir. Onun devlet memurluğunu reddiyle kamu görevlilerinin hediye kabul etmemesinin bir açıdan benzerlik gösterdiği söylenebilir. ${ }^{3}$

2 Bu niteliklerin genel olarak diğer mezhep imamları için de geçerli olduğunu söyleyebiliriz. Bu unsurların onların güvene dayalı otoritelerini nasıl inşa ettikleri hususunda şu neticeye ulaşılmıştır:

"Emevî idaresinin iktidarı ele geçirerek hilâfeti saltanata çevirmesinden sonra, toplumda adalet ve hakkaniyete aykırı icraatlara sebep olmaları ve sonra gelen Abbâsî devrinde de önemli bir değişikliğin olmamasının toplumda siyasi otoritelere karşı bir güven problemi yarattığı söylenebilir. İslam ümmetinin ilk dört halife devrine içten içe özlem duyduğu, ilk halifelerin diğer yöneticilerden farklılığını vurgulamak için "hulefâ-i râşidîn" olarak adlandırıldıkları, sadece siyasi otorite olarak ön plana çıkan idarecilere karşı ilk halifelerin siyasi yönetimleri yanında dini otoritelerine de ihtiyaç duyulduğu ve bu ihtiyacın halkın iktidarlara karşı memnuniyetsizliğine tavır ve duruşlarıyla adeta tercüman olan mezhep liderleriyle karşılandığı düşünülebilir. (Ahmet Aydın, “Dört Mezhep İmamının Otoritesini Tesis Eden Temel Unsurlar -Güven-Otorite İlişkisine Dair Bir Analiz-", Türkiye Din Eğitimi Araştırmaları Dergisi, 4 (2017): 87).

3 Kamu görevlilerinin hediye almaması ilkesinin arka planındaki saik, en güzel şekilde Ömer b. Abdülaziz tarafından vurgulanmıştır: Halife kendisine hediye olarak sunulan elmalardan birini alıp kokladıktan sonra iade eder. Bunun üzerine kendisine $\mathrm{Hz}$. Peygamber (as), Hz. Ebu Bekir ve Hz. Ömer'in hediyeleri kabul etmesine rağmen neden hediye almadığı sorulduğunda çok veciz bir cevap verir: "Onlara verilenler, hediye; onlardan sonra gelen devlet memurlarına verilenler ise rüşvettir."

Ömer b. Abdülaziz bu sözüyle, Hz. Peygambere (as) ve diğer iki halifeye hediye verenlerin ikramlarıyla onları yanlışa yönlendiremeyeceklerini gayet iyi bildiklerini, sonraki devlet memurlarına hediye verenlerin ise onların devletle ilişkili meselelerde kendilerine yardımcı olunması maksadıyla hediye sunduklarını ima etmektedir (Ebu Abdullah İbn Sa'd, et-Tabakâtü'l-kübrâ, (Beyrut: Dâru Sadır, 1968), V, 377). 
Normalde hediye, karşı tarafa yapılan bir lütuf olarak görülse de, hediye sunulan kişinin devlet memuru olması halinde "el-insân abdü'l-ihsân (insan iyiliğin kölesidir)" sözünün belirttiği gibi iyilik yapılan kişiyi etkileme, onu elde etme maksadı taşıyabilmektedir. Ebu Hanife'ye teklif edilen görev de, zahiren lütuf olarak görülmekle birlikte aynı amaca hizmet eder bir mahiyete sahiptir. Bu bağlamda onun mevcut iktidarların icraatlarını onaylamak, onların adil olmayan kararlarının bizzat uygulayıcısı konumunda bulunmak istemediğinden kamu görevini üslenmekten kaçındığı söylenebilir. Ayrıca devlet görevinin sivil ortamdaki gibi özgürce hukuk kurallarının inşası için müsait olmadığı ileri sürülebilir. Nitekim Ebu Hanife'nin Kufe kadısı İbn Ebî Leyla'nın (ö. 148) verdiği hükümleri ders ortamında öğrencileriyle tartıştığı, bu konuda yönetim tarafından uyarıldığı ve bir müddet fetva vermesinin yasaklandığı nakledilmektedir. ${ }^{4}$

Buraya kadar zikredilen bilgiler ışığında, Ebu Hanife'nin savunduğu görüş ve değerler uğruna iktidarın baskılarına bütün gücüyle direndiği ileri sürülebilir. Bu, konunun ideal yönünü oluşturmaktadır. Bir de meselenin reel boyutu vardır. Onu da, idarenin icraatları ve kadıların uyguladığı pratik hukukta görebiliriz. Ebu Hanife'nin görüşlerini eleştirdiği İbn Ebi Leyla, devletin şiddetle ihtiyaç duyduğu hukuk fonksiyonunu icra eden bir hakimdir. Ebu Hanife, onun verdiği kararları rahat şekilde eleştirmiş, kendisine yapılan kadılık teklifini kabul etmemiştir. Bu durumda, devletin hukuku nasıl ve hangi araçlarla uygulayacağı sorusu gündeme gelmektedir.

İslam tarihi boyunca Müslümanların otorite kabul ettiği fakihlerden hukuki konuları öğrenmeleri, sorularına cevap bulmaları mümkün olmuştur. Ancak özellikle devlet yaptırımının gerekli olduğu konularda mahkemelere ve onları idare eden hakimlere ihtiyaç bulunmaktadır. Ayrıca her fakihin otorite kabul edildiği, aynı konuda birçok fetvanın ortaya çıktığı durumlarda hukuk karmaşasını izale etmek de devlete kalmaktadır. Nitekim İmam Mâlik'in (ö. 179) el-Muvatta' adlı eserinin, yöneticiler tarafından kanun metni kabul edilmesine dair teklifleri, hukuki istikrarı sağlama maksadına dönüktür. Ancak İmam Malik'in Ebu Hanife'ye benzer şekilde idealist bir yaklaşımla bu teklifi reddetmesi idarecilerin önündeki problemi çözememiştir. Bunun üzerine yöneticilerin toplumda otorite kabul edilen Ebu Hanife'nin önde gelen öğrencilerinden Ebu Yusuf'u (ö. 182) kadılkudatık makamına getirerek meseleye çözüm bulmaya çalıştığı söylenebilir. Bu açıdan bakıldığında, yönetimin Ebu Hanife'ye karşı sadece kin ve düşmanlığa dayalı bir 
siyasete yönelmediği, genel anlamda hukuk problemine çözüm bulmaya çalıştığı, aksi takdirde onun öğrencilerinin hukuk alanında önemli görevlere atanmalarının beklenemeyeceği söylenebilir.

Bu noktada şu sorular ön plana çıkmaktadır: Devlet memuru oldukları andan itibaren Ebu Yusuf ve İmam Muhammed'in hukuki problemlere bakışı Ebu Hanife ile aynı olabilir mi? Yoksa onlar, idareci konumunda bulunmaları hasebiyle yönetimi daha ziyade gözeten yaklaşımla bazı meseleleri değerlendirmek durumunda kalmışlar mıdır?

Bu makalede diğer mezheplere kıyasla Hanefi hukukçuların devlet yöneticisinin yetkilerini daha ziyade ön plana çıkaran hükümlere yer verdiği tezi savunulmakta ve bu yaklaşımın Ebu Hanife'nin iktidara karşı pratik tavrından farklı olduğu vurgulanmaktadır. Hanefîler'in farklı konumu, ilgili konuda onların görüşleri diğer mezheplerin hükümleriyle mukayese edildiğinde daha belirgin şekilde ortaya çıkmaktadır. Bu nedenle, Hanefî hukukçuların görüşleri yanında diğer mezheplerin yaklaşımlarına yer verilerek mukayeseli analizler yapılacaktır.

\section{Yöneticilerin Hak ve Yetkilerinin Ön Plana Çıktığı Meseleler}

Konu iki kısımda ele alınacaktır. İlk olarak isyan suçunda Hanefi hukukçuların görüşleri incelenecek ve diğer İslam hukukçularının isyan suçuyla ilgili tespit edebildiğimiz bazı değerlendirmelerine yer verilecektir. Daha sonra devlet başkanının yetkisinin vurgulandığı bazı konularda Hanefi hukukçularla diğerleri arasındaki yaklaşım farklarına temas edilecektir. Farklı birtakım meseleleri ihtiva etmesi isyan suçunu müstakil olarak ele almayı gerekli kılmıştır.

\section{1. İsyan Suçu}

Devlet idaresiyle ilgili hususlarda Ebu Hanife'nin iktidara yönelik tavrıyla Hanefi doktrini arasındaki farkın belirgin şekilde ortaya çıktığı hususların belki de en önemlisi isyan suçuyla ilgili hükümlerdir. Nitekim Yaman, hukuk-siyaset ilişkisini incelediği makalesinde reel politiğin içtihatlar üzerindeki etkisi bağlamında ilgili konuya temas etmekte, kurucu imamlara ait tavrın sonraki hukukçular tarafından asıl mihverinden kaydırıldığını ileri sürmektedir. ${ }^{5}$ 
İsyan suçunda Yaman'ın görüşlerine paralellik arz eden bazı hususlara Hanefi metinlerde rastlanmaktadır. Örneğin Ebu Hanife'ye göre, fitne ve kargaşa anında insanların fitneden uzak durup evlerinden çıkmamaları en doğru olan tavırdır. Oysa Hanefi literatürde benimsenen görüş, Müslüman toplumun idarecinin yanında yer alarak isyancılara karşı savaşmasıdır. Bu hükümle Ebu Hanife'nin yaklaşımı arasındaki fark nedeniyle kurucu imamın sözlerinin farklı şekillerde yorumlandığı görülmektedir. Birçok Hanefi eserde Ebu Hanife'nin görüşünün herhangi bir yöneticinin mevcut olmadığı koşullara özgü olduğu ileri sürülmüş, imkanı olan kişinin isyancılara karşı yöneticiye yardım etmesinin farz olduğu belirtilmiştir. ${ }^{6}$ Kâsânî (ö. 587), Ebu Hanife'nin görüşünün yöneticinin halkı isyancılara karşı yardıma çağırmaması haline özgü olduğunu savunmuştur.?

İsyan suçunu "havâric" başlığı altında ele alan Serahsi (ö. 483), Ebu Hanife'nin fitne ve kargaşa anında insanların fitneden uzak durup evlerinden çıkmamaları görüşüne yer vererek konuya giriş yapmıştır. Daha sonra Serahsî, toplum bir yönetici üzerinde ittifak edip güven içinde yaşarken birilerinin isyan maksadıyla ortaya çıkması halinde, Müslümanların toplu şekilde isyancılara karşı koyması gerektiğini belirtmiştir. Bu konuda Serahsi "müminlerden iki grup savaştıklarında aralarını uzlaştırın. İki gruptan biri diğerine saldırırsa, saldıranlar Allah’ın dinine dönünceye kadar onlarla savaşın"8 ayetini delil olarak zikredip nasta yer alan "savaşın" emrinin gereklilik ifade ettiğini ileri sürmüştür. ${ }^{9}$

Ayrıca Hanefi hukukçular, bazı sahabilerin fitne ortamında herhangi bir tarafa katılmamalarını güç ve imkan sahibi olmamalarıyla açıklamışlardır. ${ }^{10}$

İslami Araştırmalar, 15/1-2 (2002): 277-278). Ebu Hanife'nin bu isyanları desteklediğine dair nakillerin eleştirisi için bkz. Adem Tutar, Ebu Hanife'nin Din-Siyaset İlişkisi Açısından Konumu, IV. Uluslararası Şeyh Şa'bân-ı Velî Sempozyumu -Hanefîlik-Mâturîdîlik- 05-07 Mayıs 2017, 2 (2017): 585-593.

6 Burhâneddîn Ali b. Ebî Bekr Mergînânî, el-Hidâye Şerhu Bidâyeti'I-mübtedî, (İstanbul: Kahraman Yayınları, 1986), II, 171-172; Fahreddin Osman b. Ali b. Mihcen Zeylaî, Tebyînu'l-hakâyık şerhu Kenzi'd-dekâik, (Bulak: Matbaatu'l-Kübra'l-Emîriyye, 1314), III, 294-295; Kemâleddîn Muhammed b. Abdülvâhid b. Abdülhamîd İbnü'l-Hümâm, Şerhu Fethi'l-Kadîr, (Mısır, Matbaatu Mustafâ el-Bâbî el-Halebî, 1389/1970), VI, 103.

7 Ebû Bekr Alâeddin Ebû Bekr b. Mes'ûd b. Ahmed Kâsânî, Bedâi'us-sanâi' fì tertîbi'ş-şerâi', (Beyrût: Dâru'l-Kitâbi'l-Arabî, 1402/1982), VII, 140.

8 Hucurât Sûresi, 49/9.

9 Ebû Bekr Şemsü'l-Eimme Muhammed b. Ahmed b. Sehl Serahsî, el-Mebsût, (Kâhire: Matbaatu's-Sa'âde, 1324-1331), X, 124.

10 Zeylaî, Tebyînü'l-hakâik, III, 294-295; İbnü'l-hümâm, Fethu'l-kadîr, VI, 103. 
Ebu Hanife'nin yaklaşımıyla sonraki Hanefi hukukçuların isyan suçuyla ilgili görüşleri arasındaki fark açıkça görülmektedir. Hanefi hukukçuların Ebu Hanife'nin görüşünü yorumlarken ileri sürdükleri gerekçelerin eleştiriye açık olduğu söylenebilir. Örneğin, onun fitne döneminde Müslümanların bulunduğu yerde kalması tavsiyesinin herhangi bir yöneticinin bulunmadığı dönemle ilişkilendirildiği, ancak bu koşulların tarihte neredeyse hiç olmadığı söylenebilir. Ayrıca isyan suçundan bahsedebilmek için bir yöneticiye karşı ayaklanma olmalıdır ki, bu, yöneticinin mevcudiyetini gerektirir. Aynı şekilde, Ebu Hanife'nin tavsiyesinin yöneticinin halkı isyancılara karşı hareket etmeye çağırmadığı durumlarda geçerli olduğuna dair Kâsânî'nin gerekçesi, kanaatimizce, tartışmaya açıktır. Zira Ebu Hanife, yöneticinin halkı isyancılara karşı hareket etmeye çağırması halinde icabetin gerekli olduğundan bahsetmemiştir. Ayrıca isyan dönemlerinde yöneticilerin halktan destek talep etmesi beklenir. En azından devlet yöneticileri halkın ayaklananlara destek vermemesini talep ederler ki, bu, isyan edenlere sevgi ve hoşgörü beslememeyi de ihtiva etmektedir. Ancak Ebu Hanife'nin sözünden (fitne ve kargaşa anında herkesin bundan uzak durup evinde oturması) yukarıda ileri sürülen hususlar anlaşılamayacağı gibi, onun tarih kitaplarında anlatılan biyografisinde Hanefi hukukçuların söylediği tarzda yönetimin yanında yer alma tavrı kesinlikle görülmemektedir.

Hanefi metinlerde isyan suçuyla ilgili yukarıda zikredilen görüşün dışında Ebu Hanife'nin genel yaklaşımından farklılık arz eden başka bir hüküm, isyancıların cenaze namazının kılınmasıyla ilgilidir. Hanefi mezhebinde, isyancılardan ölenlerin cenazelerinin yıkanmayacağı ve cenaze namazlarının kılınmayacağı kabul edilmiştir. ${ }^{11}$ Serahsî, bu görüşü Muallâ b. Mansur'un (ö. 211) İmâmeyn'den naklettiğini belirtmiştir. ${ }^{12}$ Kâsânî, bu görüşü Muallâ b. Mansur'un Ebu Yusuf kanalıyla Ebu Hanife'den aktardığını belirttikten sonra bunun İmâmeyn'e ait bir hüküm olduğunu açıklamıştır. ${ }^{13}$ Serahsî ve Kâsânî'nin metinlerinden bu görüşün Ebu Hanife'ye değil; İmameyn'e ait olduğu anlaşılmaktadır.

Hanefi eserlerde bu hükmün gerekçesi, isyancıların Müslümanlarla savaş halinde öldürülmeleri, bu nedenle cezalandırılmaları ve cezanın diğerleri için caydırıcı olmasıyla açıklanmıştır. ${ }^{14}$ Cenaze namazının kılınmama yaptırımı, herhangi bir suç- 
tan dolayı idam cezası verilen kişinin asıldığı yerde bırakılması ve bunun başkaları için caydırıcı olmasına benzetilmiştir. ${ }^{15}$ Yani her iki ceza da caydırma amaçlıdır.

Şâfiî mezhebinde ise isyancıların cenazeleri yıkanır ve namazları kılınır. ${ }^{16}$ Hanbeli mezhebi de Şâfiî mezhebinin görüşünü savunmuştur. ${ }^{17}$ Mâlikîler, fazilet ehli kişilerin ve devlet başkanının, isyancıların cenaze namazını kılmayıp diğerlerinin bu görevi ifa edeceğini ileri sürmüşlerdir. ${ }^{18}$

Mezheplerin görüşleri incelendiğinde, Hanefi mezhebinin bu konuda en uçta yer aldığı ve isyancılara karşı sert bir tutum sergilediği söylenebilir. Bu konuda onları Maliki mezhebinin takip ettiği ileri sürülebilir. İsyancıların cenaze namazlarının kılınması hususunda hoşgörülü tavrın Şafii ve Hanbeliler tarafından benimsendiği anlaşılmaktadır. İsyancıların cenaze namazı konusunda, Hanefî ve Malikî mezhebinin bir tarafta, Şafiî ve Hanbelîler'in diğer kısımda yer aldığı söylenebilir. Mezheplerin görüşleriyle ilgili benzer bir durum, isyancılara yönelik savaş metotlarına dair hükümlerde de görülmektedir.

Şâfiî ve Hanbelî mezhebinde mancınık atma, sel gönderme, yangın çıkararak zarar verme gibi kitle imha edici silah olarak tabir edilebilecek vasıtalar (Müslümanların başka şekilde kurtulma imkanı bulamadığı koşullar hariç) isyancılara karşı kullanılamazken ${ }^{19}$; Hanefî mezhebinde koşulsuz olarak isyancılara karşı bu silahlarla savaşılacağı belirtilmiştir. ${ }^{20}$ Şâfiî hukukçular görüşlerini savunurken, önemli olan hususun onları itaate döndürmek olduğunu; kitle yok edici nitelikte silahların kullanılması halinde bu maksada ulaşılamayacağını ileri sürmüşlerdir. ${ }^{21}$ Hanefî hukukçular ise isyancılarla savaşın mürted ve düşmanla harp hükmünde olduğundan kitle imha edici silahların kullanılabileceğini belirtmişlerdir.22 Mâlikî

Serahsî, Mebsût, II, 53, Zeylaî, Tebyînü'l-hakâik, I, 249-250.

Ebü'l-Hasan Ali b. Muhammed Mâverdî, el-Hâvi'l-kebîr fî fıkhi'ş-Şâfiî, (Beyrut: Dâru'l-Kütübi'l-ilmiyye, 1994), III, 37.

Muvaffakuddîn Abdullah b. Ahmed İbn Kudâme, el-Muğnî, (Beyrut: Dâru İhyâi't-Türâsi'l-Arabî, t.y.), Il, 207; Mustafa es-Suyûtî Ruhaybânî, Metâlibü üli'n-nühâ fî şerhi Gâyeti'l-müntehâ, (Dımaşk: el-Mektebü'l-İslâmî, 1961), VI, 269.

8 Muhammed b. Ahmed b. Muhammed İlîş, Minehu'l-celîl alâ muhtasarı Halîl, (Beyrut: Dâru'l-Fikr 1989), I, 513.

Ebû Hamid Huccetülislam Muhammed b. Muhammed Gazzali, el-Vasît fi'l-mezheb, (Kâhire: Dâru'l-İslam, 1417), Vl, 422; Şemseddîn Hatîb Muhammed b. Ahmed Şirbînî, Mugni'I-muhtâc ilâ ma'rifeti meânî elfâzi'l-Minhâc, (Beyrut: Dâru'l-Fikr, t.y.), IV, 127; İbn Kudâme, Mugnî, IX, 7; Şeyh Mansûr b. Yûnus b. Selâhiddîn Buhûtî, Keşşâfü'l-Kınâ' an metni'l-iknâ', (Beyrut: Dâru'I-Fikr, 1982), VI, 163.

Serahsî, Mebsût, X, 128-129.

Şirbînî, Mugni'l-muhtâc, IV, 127.

Serahsî, Mebsût, X, 128-129. 
mezhebinde isyancıların içinde çocuk ve kadınlar olmadığı takdirde onlara karşı kitle imha edici silah kullanımı uygun görülmüştür. ${ }^{23}$

İsyan suçu bağlamında Hanefilerle diğer mezhepler arasındaki diğer bir görüş farklıığı, isyancılara karşı savaşa başlama koşullarında görülmektedir.

Şâfiî ve Hanbelî hukukçular, isyancıların isyan gerekçelerini öğrenmek için kendileriyle iletişim kurabilecek birtakım şahısların onlara gönderilmesi ve isyan gerekçesinin ortadan kaldırılması gerektiğini; bundan önce onlarla savaşılmayacağını kabul etmişlerdir. ${ }^{24}$ Hanefî mezhebinde ise, isyancıları savaştan önce adalete çağırmanın uygun bir metot olduğu (ينبغي لأهل العدل); ancak bunu yapmanın sorumluluk doğurmadığı ileri sürülmüştür. Gerekçe olarak, bu şekilde bir çağrı durumunda isyancıların kendilerine yönelik savaş hazırlığından haberdar olmalarına yer verilmiştir. ${ }^{25}$

İbnü'l-Hümam (ö. 861), isyancılara yönelik savaşın başlaması hususunda Hanefi mezhebiyle diğerleri arasındaki görüş farklılığını şu şekilde aktarmaktadır: Hanefilere göre, isyancılar silahlanıp toplandıklarında kendilerine karşı savaş başlatılabilir. Şafiiler'e göre isyancılar savaşa başlamadan onlarla harbe girişilmez. İbnü'l-Hümam, Maliki ve Hanbeli mezhebinin de Şafiiler ile aynı görüşü paylaştığını ileri sürmektedir. ${ }^{26}$

\section{2. İsyan Suçu Haricindeki Konular}

Bu başlık altında fıkıh kitaplarında devlet başkanının hak ve yetkilerinin, özellikle, Hanefîler tarafından ön plana çıkarıldığı bazı konular ele alınacaktır.

\subsubsection{Devlet Başkanına Had Cezasının Tatbik Edilmemesi}

Hanefi mezhebinde, had suçunu işleyen devlet başkanına ceza tatbik edilmeyeceği kuralı benimsenmiştir. Bunun gerekçesi açıklanırken, had cezalarını uygulamanın devlet başkanının yetkisinde olduğu, onun da kendisine bu cezayı 
tatbik etmesinin mantıklı olmadığı, herhangi birinin de ona vekaleten bu cezayı yöneticiye uygulayamayacağı belirtilmiştir. Cezanın gerekliliği onun uygulanabilir olmasıyla ilişkilidir. Tatbik imkanı olmadığında ise, artık had cezası vacip olma vasfını yitirir. ${ }^{27}$ Udeh, had cezası hususunda diğer mezheplerin Hanefilerden farklı olarak tatbik imkanını ölçü almayıp devlet başkanını diğer fertlerle aynı değerlendirdiğini belirtmiştir. Cumhurun görüşünü daha isabetli bulan Udeh, hadlerin tatbiki hususunda tek yetkilinin devlet başkanı olmadığını, bu konularda ona vekalet edecek kişilerin bu cezayı kendisine tatbik edebileceğini ileri sürmüştür. ${ }^{28}$ Nitekim Şafiî hukukçu Şirbînî (ö. 977), devlet başkanı zina suçunu icra etmesi halinde görevden alınmamakla birlikte ilgili konularda onu temsil eden kişinin ilgili cezayı yöneticiye tatbik edebileceğini savunmuştur. ${ }^{29}$

Hanefilerin görüşü cezalarda genellik ilkesine aykırı olmakla birlikte, günümüz hukukunda milletvekili ve cumhurbaşkanının dokunulmazlığı gibi kurallarla benzerlik arz etmektedir. Ayrıca Hanefilerin cezanın uygulanamaz oluşuna vurgu yapmaları, realist hukuk yaklaşımı olarak değerlendirilmelidir. Serahsî'nin söz konusu hükmü doğrudan Ebu Hanife'nin görüşü olarak aktarması, makalemiz açısından önem arz etmektedir. ${ }^{30}$

\subsubsection{Cuma Namazı İçin Devlet Başkanının İzni}

Cuma namazı cemaatle haftada bir kez ifa edilen ibadettir ve fıkıh eserlerinde diğer namazlardan farklı olarak onunla ilgili bazı sıhhat şartlarına yer verilmektedir. Bunlardan biri, Hanefi mezhebinde cuma namazının kılınabilmesi için devlet başkanının izninin gerekli görülmesidir. ${ }^{31}$ Bu hükümle ilgili Hanefi füru eserlerde genelde maslahat ve sedd-i zerai ilkelerine paralel gerekçelere yer verilmektedir. $^{32}$ Serahsî, birtakım karışıklıkların önlenmesi açısından Cuma namazı husu-

28 Abdülkâdir Udeh, et-Teşrîu'l-cinâiyyü'l-Islâmî: Mukârenen li-kânûni'l-vaz'î, (Kâhire: Dâru't-Türâs, 1977), I, 322-323.

29 Şirbînî, Mugni'l-muhtâc, IV, 152.

30 Serahsî, Mebsût, IX, 105.

31 Serahsî, Mebsût, II, 25; Kâsânî, Bedâi', I, 261.

32 Hanefî mezhebinde konuyla ilgili bazı nakli delillere de yer verilmektedir. Diğer mezhepler tarafından zayıf görülen ve itibara alınmayan bu delillerin detaylı analizi için bkz. Recep Çetintaş, Hanefiler'in Cuma Namazını Devlet Başkanı veya İzin Verdiği Kimselerin Kıldırması Şartıyla Kayıtlamasına Usûlî Bir Bakış, Cumhuriyet Üniversitesi Illahiyat Fakültesi Dergisi, 18/2 (2014): 207-240. 
sunda devlet başkanının iznine ihtiyaç duyulduğunu, onun tarafından bir imam tayin edilmediği takdirde bazı kimselerin cemaat oluşturarak namazı erken kılma, diğerlerinin de ona yetişememe ihtimalinin bulunduğunu, bunun da sıkıntıya sebebiyet vereceğini ileri sürmektedir. ${ }^{33}$ Kâsânî, Cuma namazının bütün şehir halkının toplanıp ifa ettiği bir ibadet olduğundan burada imametin çok önemli bir vazife kabul edilmesi sebebiyle birçok kişinin toplumun önünde bulunma arzusuyla imamlığa geçmek isteyeceğini, bunun da karışıklığa, sıkıntıya neden olacağını belirtmektedir. ${ }^{34}$

Malikî mezhebinde genel kural, Cuma namazının ifa edilmesinde devlet başkanının izninin şart olmamasıdır. Bununla birlikte, Cuma namazı kılmak onun tarafından yasaklandığında Malikiler meseleyi iki açıdan ele almışlardır. İnsanlar, yasakla birlikte yöneticiye karşı kendilerini güvende hissediyor, bu namazı kıldıklarında kendilerine zarar gelmeyeceğini düşünüyorlarsa ibadeti yerine getirirler. Aksi takdirde devlet başkanının izni olmaksızın Cuma namazının kılınması halinde bunun geçerli olmayacağı belirtilmiştir. Burada dikkate alınan husus, içtihada dayalı konuda devlet başkanı bir kural belirlediğinde ona itaat edilmesinin vacip olmasıdır. Aksi takdirde ona karşı çıkmak kargaşaya neden olur. Bu ise, helal kabul edilmemiştir. Yapılması helal olmayan bir fiili icra ederek vacip bir ibadetin yerine getirilmesi ise düşünülemez. ${ }^{35}$ Sonuç olarak Malikîler Cuma namazının kılınması hususunda devlet başkanının iznini şart koşmamakla birlikte, konuyu devlet başkanının yetkisi, ona itaat, toplum yararı açılarından ele alarak Hanefiler'e benzer bir yaklaşım sergilemişlerdir.

Şafiî mezhebinde devlet başkanından izin alınması müstehab kabul edilmiş; ancak şart olarak değerlendirilmemiştir. ${ }^{36}$ Hanbelî mezhebinde de Cuma namazı için devlet başkanının izni gerekli görülmemiştir. ${ }^{37}$

Serahsî, Mebsût, II, 2.

Kâsânî, Bedâi', l, 261.

Ebû Abdullah Muhammed b. Abdullah el-Mâlikî Haraşî, Şerh alâ muhtasarı Hâlîl, (Beyrut: Dâru'l-Fikr, t.y.), II, 84-85; Derdîr, eş-Şerhu'l-kebîr, I, 384; Desûkî, Hâşiye, I, 384.

Yahyâ b. Şeref en-Nevevî, el-Mecmû' Şerhu'l-Mühezzeb, (Kâhire: el-Matbaatü'l-Mûniriyye, t.y.) IV, 44-45; Zekeriyyâ b. Muhammed b. Ahmed Ensârî, Esne'l-metâlib Şerhu Ravzi't-tâlib, (Beyrut, Dâru'l-Kütübi'l-IIlmiyye, 2000), l, 251.

İbn Kudâme, el-Muğnî, II, 90; Şeyh Mansûr b. Yûnus b. Selâhiddîn Buhûtî, Şerhu Müntehel-irâdât, (Beyrut: Âlemü'l-Kütüb, 1996), I, 311. 


\subsubsection{Zina Suçuna Sürgün Cezası Verilmesinde Devlet Başkanının Yetkisi}

İslam hukukunda bekar şahısların zina suçunu icra etmesi halinde onlara uygulanacak celde (sopa) cezası Kuran- Kerim'de belirtilmiştir. ${ }^{38}$ Sünnette ise celde cezası yanında bekar kişilerin sürgün edilmelerine yer verilmiştir. ${ }^{39}$ Cumhur, ilgili hadisin ışığında zina yapan bekar suç faillerine celde ile birlikte sürgün cezası uygulanacağını savunarak bu konuda devlet başkanına takdir hakkı tanımamışlardır. ${ }^{40}$ Hanefîler ise, zina suçunu icra eden bekarlara uygulanacak yaptırımın celde olduğunu; ayrıca sürgün cezası tatbikinin ise devlet başkanının yetkisinde bulunduğunu ileri sürmüşlerdir. ${ }^{41}$

\subsection{4. Ölü Araziye Sahip Olmada Devlet Başkanının Yetkisi}

Hanefî mezhebinde, İmameyn'e göre bir şahıs ölü araziyi ihya ederek ona malik olabilir. Nitekim bu konuda Hz. Peygamber (as) bir araziyi ihya eden kişinin ona sahip olacağını belirtmiştir. ${ }^{42}$ Onlar, ihya yoluyla araziye sahip olmayı av avlama veya başkasına ait olmayan odun ve ot toplamaya kıyas etmişlerdir. Ebu Hanife ise bu konuda devlet başkanının izninin gerekli olduğunu belirtmiştir. Ebu Hanife, ilgili meselede sadece devlet başkanının gönül hoşluğuyla verdiği şeye kişinin sahip olacağını ifade eden hadisle ${ }^{43} \mathrm{Ad}$ kavmi arazisinin ${ }^{44}$ Allah ve Rasülüne ait olduğunu belirten rivayeti ${ }^{45}$ delil almıştır. Buna göre, Allah ve Rasülü'ne izafe edilen şeyde kamu idaresinin düzenleme yetkisi bulunmaktadır. Ebu Hanife bu meseleyi ganimetlerin beşte birinde kamu idaresinin takdir hakkının bulunmasına kıyas etmiştir. ${ }^{46}$

Nûr Sûresi, 24/2.

Ebû Abdullah Muhammed b. İsmâîl el-Buhârî, el-Câmi'us-Sahîh, (İstanbul: Dârü't-Tıbâati'l-Âmire, 1315), Şehâdât, 8; Ebû Dâvûd Süleymân b. Eş'as b. İshâk el-Ezdî es-Sicistânî, Kitâbü's-Sünen, Muhammed Avvâme (thk), (Cidde: Dârü'l-Kıble li's-Sekâfeti'l- İslâmiyye, 1998/1419), Hudûd, 24.

Ebul Velîd Muhammed b. Ahmed İbn Rüşd (Hafîd), Bidâyetül-müctehid ve nihâyetül-muktesıd, (Mısır: Matbaatü Mustafa el-Bâbî el-Halebî ve Evlâdühû, 1975), Il, 436; Şirbînî, Mugni'l-muhtâc, IV, 147-148; İbn Kudâme, el-Mugnî, IX, 45-46. Malikîler bazı sakıncalardan dolayı kadınlara sürgün cezasını uygun görmemiştir (İbn Rüşd (Hafîd), Bidâyetül-müctehid, II, 436).

Serahsî, Mebsût, IX, 44; ; Kâsânî, Bedâi', VII, 39.

Ebu Davud, Sünen, Harac, 37.

Ebû Bekr Ahmed b. el-Hüseyin b. Ali Beyhakî, Ma'rifetü's-sünen ve'l-âsâr, (Kâhire: Dâru'l-Vefâ, 1991), İhyâi'l-mevât, 1.

Bu hadisteki Ad kavmi, Hz. Hud Peygamberin (as) milletidir. Bu kavim yok olunca yaşadıkları topraklar ölü arazi statüsü kazanmıştır. Üzerinde yaşayan halkın bulunmadığı bütün yerler için Ad kavmi arazisi ifadesi kullanılmaktadır.

Ebû Davud, Sünen, Harâc, 35.

Serahsî, Mebsût, III, 16; Kâsânî, Bedâi', VI, 194-195. 
Mâlikî hukukçular, sahipsiz arazileri ihya yoluyla mülk edinmenin çöl gibi yerleşim yerlerine uzak coğrafyalar için geçerli olduğunu; şehre yakın yerlerde kamu idaresinin izninin şart olduğunu savunarak Ebu Hanife'nin yaklaşımına benzer bir görüş benimsemişlerdir. ${ }^{47}$

Şâfiî ve Hanbelî hukukçular, İmâmeyn gibi Hz. Peygamberin sözünü genel kural olarak yorumlayıp ilgili meselede kamu idaresinin iznine ihtiyaç bulunmadığını belirtmişlerdir. ${ }^{48}$

İmameyn, Şafiî ve Hanbelî hukukçuların hadisin zahirini dikkate alarak hükme varırken, kamu idaresinin düzenleme yetkisini göz ardı ettikleri söylenebilir. İlgili meselede devlet başkanına en geniş yetki tanıyan hukukçunun Ebu Hanife olduğu görülmektedir. Ebu Hanife'nin görüşlerinde kamu idaresi, devlet başkanının düzenleme yetkisi, toplum nizamı gibi kavramların ön plana çıktığı aşikardır. Devlet yöneticilerinin ısrarlı görev tekliflerini reddeden Ebu Hanife'nin ilgili konuda Hz. Peygamberin (as) "kişiye sadece devlet başkanının gönül hoşluğuyla verdiği şeyin helal olduğuna" dair sözünü49 ${ }^{49}$ delil olarak zikretmesi dikkat çekicidir.

\subsubsection{Selebin Hak Edilmesinde Devlet Başkanının Yetkisi}

Seleb, savaşta öldürülen düşman askerinin üzerinde veya yanında bulunan elbise, silâh vb. eşyayı ifade eden fıkıh terimi olarak tanımlanmıştır. ${ }^{50}$ Selebe hak kazanılmasında fakihler farklı görüşler belirtmişlerdir.

Şafiî ve Hanbelîler, düşman askerini öldüren kişinin onun selebine hak kazanacağını vurgulayan hadisi ${ }^{51}$ itibara almış ve bu sözün bütün zamanlar için geçerli olduğunu ileri sürmüşlerdir. ${ }^{52}$

Hanefîler'den Serahsî, bu sözün savaş esnasında söylenmesini itibara alarak kural koyma maksadıyla değil; askerleri savaşa teşvik amacıyla dile getirildiğini belirtmiş ve devlet başkanının izni olmaksızın askerin selebe sahip olamayacağını savunmuştur. ${ }^{53}$

Şehâbeddîn Ahmed b. İdrîs Karâfî, Zehîra, (Beyrût: Dâru'I-Garbi'l-Islâmî, 1994) VI, 156; Derdîr, eş-Şerhu'l-kebîr, IV, 69; Haraşî, Şerh, VII, 70. Mâverdî, Hâvî, VII, 478; Ensârî, Esne'I-metâlib, II, 445; Ibn Kudâme, Mugnî, V, 347; Buhûtî, Şerh, II, 364.

50 Ahmet Yaman, "Seleb", DiA, (İstanbul: Diyanet Vakfı Yayınları, 2009), XXXVI, 398-399.

51 Buhârî, Sahîh, Humus, 18.

52 Ensârî, Esne'I-metâlib, III, 94; Şirbînî, Mugni'l-muhtâc, III, 99; Buhûtî, Keşşâf, III, 71.

53 Serahsî, Mebsût, X, 49. 
Malikî mezhebinde Karâfî (ö. 684), Hz. Peygamberin (as) sözünün fetvayla ilişkili olmadığını, devlet başkanlığı tasarrufuyla ilgili olduğunu, kamu idaresinin izni olmaksızın selebe hak kazanılamayacağını belirtirken Serahsî'nin ifadelerine benzer bir görüş ortaya koymuştur. ${ }^{54}$

Dikkat edilirse makalede zikredilen birçok meselede olduğu gibi bu hükümde de, Hanefî ve Malikîler bir tarafta, Şâfiî ve Hanbelîler onların karşısında yer almaktadır.

\subsubsection{Fethedilen Toprakların Askerlere Dağıtımında Devlet Başkanının Yetkisi}

Kuran- Kerim'de (Enfal Suresi, 41. ayet) savaşta elde edilen ganimetlerin beşte birinin kamuya tahsis edileceği belirtilmiştir. Ganimetlerin bunun dışındaki kısmı ise savaşa katılanların hakkı olmaktadır. Ayette ganimetlerin menkul veya gayri menkul ayrımına temas edilmemiştir. Uygulamada Hz. Peygamber (as), Benî Kureyza, Hayber gibi toprakları savaşçılara taksim etmiştir. Hz. Ömer'in hilafeti döneminde ise Irak ve Suriye toprakları mücahidlere dağıtılmayıp vergi karşılığında sahiplerinin ellerinde bırakılmıştır. ${ }^{55} \mathrm{~Hz}$. Peygamber (as) ve Hz. Ömer'in farklı tatbikatlarını değerlendiren İslam hukukçuları bu konuda muhtelif görüşler benimsemişlerdir.

Hanefî hukukçular ${ }^{56}$ fethedilen toprakların savaşa katılanlara dağıtımı veya vergi karşılığında sahipleri elinde bırakılması hususunda devlet başkanının yetkili olduğunu ileri sürmüşlerdir. Malikî literatürde genelde toprakların savaşa katılanlara dağıtılmayıp Müslümanlara ait vakıf arazisi statüsü kazanacağı (topraktan elde edilen vergilerin kamu yararına harcanacağı) görüşüne yer verilmiştir. ${ }^{57}$ Ayrıca savaş yoluyla elde edilen toprakların içtihad konusu olduğuna ${ }^{58}$, hatta devlet başkanının uygun görmesi halinde taksim edileceğine dair görüşler ileri sürülmüştür. ${ }^{59}$ Şâfiî hukukçular, savaşçıların rızası alınmaksızın ganimete dahil olan arazilerin, sahipleri elinde bırakılamayacağını ileri sürmüşlerdir. ${ }^{60}$ 
Hanbelî eserlerde, savaş yoluyla fethedilen arazilerin savaşanlara dağıtılması veya Müslümanlara ait vakıf arazisi olarak tahsisi hususunda devlet başkanının yetkili olduğu kabul edilmiştir. ${ }^{61}$ Hanbelîler, fethedilen yerlerin Müslümanlara ait vakıf arazisi olarak kabulü hususunda Malikîler ile benzer görüş benimsemişlerdir. Diğer taraftan asıl dikkat çekici olan, makalede incelenen devlet başkanının yetkisiyle ilgili meselelerde genelde Şafiî mezhebiyle benzer görüşlere sahip olan Hanbelîlerin bu konuda istisna olarak Hanefîler'e yakın bir konumda yer almalarıdır. Malikiler genelde devlet başkanına ilgili konuda takdir hakkı tanımazken; bazı Maliki hukukçuların buna yer vermesi, ilgili mezhebin devlet başkanına birçok meselede takdir hakkı tanımada Hanefîler'e yakın konumda bulunmasıyla uyumluluk arz etmektedir.

\subsubsection{Mahkeme Kararının Hukukî ve Dinî Mahiyeti}

Toplumda sorunların çözülmesi, haksızlıkların giderilmesi, adaletin sağlanması için hukuk sistemine ihtiyaç duyulmaktadır. Ancak yargı sistemi somut delillere dayandığından haksızlığa uğrayan şahsın zararının mahkemeler tarafından giderilmesi her zaman mümkün olmamaktadır. Bu noktayı göz önünde bulunduran İslam hukukçuları kazaî-diyanî ayrıma gidip, örneğin, yalan tanıklığa dayalı mahkeme kararının kazaen geçerli; diyâneten geçersiz olduğunu belirtmişlerdir. Buna göre mahkemede sahte delillerle lehine karar alınmasını sağlayan şahıs, dünyevî ahkam açısından kovuşturmaya tabi tutulmazken; uhrevî sorumluluktan kurtulamayacaktır. ${ }^{62}$

Kazaî-diyanî ayrımla ilgili İslam hukukçularının genel yaklaşımı yukarıda belirtildiği şekilde olmakla birlikte, Hanefî eserlerde Ebu Hanife'ye atfedilen farklı bir görüşe yer verilmektedir. Buna göre, bir tanığın mahkemede kocanın eşini boşadığına dair yalan beyanda bulunmasından sonra hakimin yalan tanıklığa binaen eşleri ayırması halinde, şahidin boşanan kadınla evlenerek onunla cinsel ilişkiye girmesi, Ebu Hanife'ye göre kazâen ve diyâneten geçerlidir. Ebu Hanife, bu hükme varırken hakimin kararının kazaî ve diyanî açıdan geçerli olduğu, haramı he- 
lal kıldığını ileri sürmüştür. İmâmeyn ise, ilgili meselede hakimin kararının sadece kazâen geçerli olduğunu, diyâneten kabul edilmeyeceğini savunmuşlardır. ${ }^{63}$ Diğer üç mezhep de İmâmeyn ile aynı görüştedir. ${ }^{64}$

Hakimin kararının niteliği konusunun makalemizle ilişkisi, yargının devletin bir fonksiyonu olması, hakimin devleti temsilen hükümlere varmasıdır. Bir açıdan hakimin hükmü devlet başkanının kararı olarak değerlendirilebilir. Nitekim kadıları tayin eden devlet başkanıdır. Bu bağlamda, Ebu Hanife tarafından hakimin kararına, kamu otoritesine diğer hukukçuların aksine farklı bir önem atfedildiği söylenebilir. Bu noktada Ebu Hanife ve İmameyn'in iki açıdan zıt konumda yer almaları dikkat çekicidir. Bir tarafta kamu görevi icra eden İmâmeyn; diğer tarafta bunu kesinlikle kabul etmeyen Ebu Hanife. İmâmeyn hakimin kararına sadece zâhiren bir geçerlik atfederken; kadıık görevinden hayatı boyunca uzak duran Ebu Hanife ise hakimin kararının haramı helal kıldığını savunmaktadır.

\section{Devlet Başkanının Yetkileri Konusunda Mezheplerin Görüşlerinin Değerlendirilmesi}

Devlet başkanının yetkileri hususunda mezheplerin yaklaşımı makalede sınırlı sayıda bazı meselelerde incelenmiştir. Ele alınan örneklerde Hanefîlik, yönetimin yararını daha ön planda tutan, devlet başkanına daha ziyade yetkiler tanıyan mezhep olarak karşımıza çıkmaktadır. Onları bu konuda Malikiler'in takip ettiği söylenebilir. Diğer taraftan Şafiî ve Hanbelî mezheplerinin devlet başkanına daha az takdir hakkı tanıdığı görülmektedir. Bu husus, isyan suçuyla ilgili hükümlerde ve makalede incelenen diğer meselelerde belirgindir. Diğer taraftan, ilgili meselelerde mezheplerle ilgili farklı yaklaşımlar istisnaî olarak yer almıştır. Fethedilen toprakların savaşa katılanlara dağıtımı veya kamu yararına tahsisi hususunda devlet başkanına yetki tanıyan Hanbelîler, Hanefîler ile aynı görüşü benimserken; genelde Malikî hukukçular ve Şafiî mezhebi bu konuda kamu idaresine tercih hakkı sunmamıştır.

Belirtmek gerekir ki, makalenin sınırları açııından sadece birkaç konuya temas edilmekle birlikte seçilen meselelerin ilgili konuda genel fikir verecek düzeyde olduğu kanaatindeyiz. Araştırmada yer vermediğimiz birtakım konularda mezhep- 
lerin farklı yaklaşımlarına ulaşmak ihtimal dahilindedir. Nitekim devlet başkanına daha ziyade takdir yetkisi tanıma hususunda Hanefîler'in geri planda kaldığı bazı meseleler tespit edilmiştir. Örneğin, tazir olarak uygulanacak sopa cezasının sayısı hususunda Hanefîler dahil cumhur, muayyen miktarlar belirlerken, ${ }^{65}$ Malikîler ilgili konuda takdirin devlet başkanına ait olduğunu savunmuşlardır. ${ }^{66}$ Ayrıca Hanefî, Şâfiî ve Hanbelîler, hırâbe suçunu icra eden faillere tatbik edilecek cezanın mahiyetini eylemin ağırlığına göre belirleyip kamu idaresine takdir hakkı tanımazken; Malikiler bu hakkı bir noktaya kadar uygun görmüşlerdir. ${ }^{67}$

Bu iki örnekte Malikiler'in devlet başkanına takdir hakkı tanımada Hanefîler'den önde olduğu görülmektedir. Bu bağlamda zikredilen örnekler makalede savunulan Hanefîler'in devlet başkanına takdir hakkı tanımada en uçta yer alan mezhep olduğu görüşüne aykırı görülebilir. Ancak araştırmamızda yer verilen meselelerde genelde Malikiler'in Hanefiller ile benzer görüşlere sahip oldukları hususu gözden uzak tutulmamalıdır. Bu açıdan, zikredilen iki örnekte Malikiler'in konumunun makalede verilen örnekler ve savunulan tezle paralellik arz ettiği söylenebilir.

Makalede incelediğimiz meselelerde, Hanefî ve Malikîler'in devlet başkanına diğerlerine kıyasla daha ziyade yetkiler tanımasının her iki ekolün tarih boyunca İslam devletlerinde diğerlerine nispetle daha etkili olmalarıla paralellik arz ettiği kanaatindeyiz. Nitekim Hanefî mezhebi İslam coğrafyasında altı asır varlığını sürdüren Osmanlı devletinde resmi mezhep statüsü kazanmıştır. Ondan önce Ebu Yusuf ve ardından İmam Muhammed'in kadılkudat olarak atandığı Abbasiler döneminde de Hanefiller'in buna yakın konumda olduğu değerlendirilebilir. Malikîler'in Kuzey Afrika ve Endülüs'te genelde tek etkili mezhep olması ve kadılık makamına bu ekole mensup hukukçuların atanması göz önüne alındığında Malikilik'in Hanefîler'e yakın bir konumda yer aldığı söylenebilir. Makaledeki örneklerde devlet başkanına bu iki ekole kıyasla daha az yetki tanıyan Şafiî ve Hanbeliler'in tespit edebildiğimiz kadarıyla genelde İslam devletlerinde diğerleri kadar etkili olamadıkları anlaşılmaktadır. Bunun iki istisnası Memlükler döneminde dört mezhebe ait kadıların atanması ve Eyyübîler döneminde Mııı'da Şafiî mezmuhtâc, IV, 193; İbn Kudâme, Mugnî, IX, 149. 
hebinin ayrıcalıklı konumda yer almasıdır. Bununla birlikte İslam tarihinde hakim mezhep konumu göz önüne alındığında, Şafiî ve Hanbelîler'in Hanefî ve Malikîlik kadar devletlerle güçlü ilişkileri olmadığı söylenebilir. Kaynaklarda doğuda Hanefiliğin, batıda ise Maliki mezhebinin devlet otoritesiyle yayıldığına ${ }^{68}$ temas edilmesi bu değerlendirmelerimizi destekler niteliktedir. Sonuç olarak mezheplerin devletlerle resmi ilişkisinin derecesiyle onların yönetimle ilgili konulardaki yaklaşımları arasında uyum olduğu kanaatindeyiz. ${ }^{69}$

\section{Devlet Başkanının Yetkileri Konusunda Ebu Hanife'nin Görüşlerinin Değerlendirilmesi}

Makalede yer verilen örneklerde, Hanefî hukukçular diğer mezheplerle mukayese edildiğinde devlet başkanına daha ziyade yetkiler tanımakta, yönetimin lehine hükümlere varmaktadır. Bu, İmameyn'in kamu görevi icra etmesi ve Hanefîler'in genelde devletlerle güçlü ilişkisiyle paralellik arz etmektedir. Diğer taraftan Ebu Hanife'nin yönetimlere karşı tavrı düşünüldüğünde farklı bir durum söz konusudur. Nitekim Ebu Hanife'nin yönetimlerin teklif ettiği görevleri kabul etmediği için işkence gördüğü ve bazı isyanları desteklediğine dair rivayetler bulunmaktadır. ${ }^{70}$ Onun hayatındaki bu pratikle genelde Hanefî mezhebi özelde Ebu Hanife'nin devlet yöneticilerinin hak, yetki ve ayrıcalıklarını diğer hukukçulara kıyasla daha ziyade ön plana çıkaran teorik yaklaşımları arasındaki farklıık nasıl izah edilecektir?

Ali Bardakoğlu, "Hanefî Mezhebi", DiA, (İstanbul: Diyanet Vakfı Yayınları, 1997), XVI, 4.

Bu hususu belirten farklı bir araştırma için bkz. Ahmet Aydın, "Hz. Ömer'in Uygulamalarını Devlet Başkanının Tasarruf Yetkisi Bağlamında Değerlendirmek", II. Uluslararası Multidisipliner Çalışmalar Sempozyumu Tam Metin Bildiriler Kitabı Sosyal Bilimler içinde. Bu bildiri 16-17 Kasım 2018 tarihleri arasında II. Uluslararası Multidisipliner Çalışmalar Sempoyzumu'nda sunulmuştur. (Ankara: Berikan Matbaacılık, 2018), 19-32. Hz. Ömer'in öncekilerden farklılık arz eden uygulamalarını kamu idaresinin tasarruf yetkisi bağlamında analiz eden bu bildiride fethedilen ülke topraklarının dağıtımı hususunda Hanefi mezhebinin devlet başkanına yetki tanırken, Şafii hukukçuların bunu uygun görmediğine yer verilmiştir (Aydın, Hz. Ömer, 21-22). Ayrıca sahipsiz arazilerin mülk edinilmesi hususunda Hanefî ve Malikî mezhebinin devlet başkanına yetki tanırken, Şafii mezhebinin meseleyi farklı değerlendirdiğine temas edilmiştir (Aydın, $\mathrm{Hz}$. Ömer, 27-28). Bu makalede ise zikri geçen iki konunun yanında farklı meselelere temas edilmiş, mümkün olduğunca dört mezhebin ilgili meselelerdeki görüşlerine yer verilerek mukayeseli analizler yapılmıştır. Zikri geçen bildiride $\mathrm{Hz}$. Ömer'in tasarrufları değerlendirilirken; bu makalede üzerinde durulan husus, Ebu Hanife'nin yönetimle ilişkisinde ortaya çıkan teori-pratik farklıı̆ı̆ıdır.

Uzunpostalcı, Ebu Hanife, X, 133. 
Devlet başkanının yetkileri hususunda Ebu Hanife ile ilgili teori-pratik farklılığını izale etmek maksadıyla onun yönetime karşı tavrının (pratik) ve idareyle ilgili görüşlerinin (teori) yeniden değerlendirilmesi mümkün gözükmektedir. Konunun pratik yönüyle ilgili olarak, onun hayatıyla ilgili nakiller, örneğin, onun birtakım isyanları gerçekte destekleyip desteklemediği ortaya konabilir. Nitekim Ebu Hanife'nin döneminde ortaya çıkan birtakım isyanları desteklediğine dair nakillerin sıhhati bazı araştırmacılar tarafından eleştirilmektedir. ${ }^{71}$ Isyan suçunu maddeten desteklemenin devletler tarafından genelde ölümle cezalandırılması göz önüne alındığında, bu eleştirinin isabetli olduğu söylenebilir. Diğer taraftan onun kendi dönemindeki isyanlarla alakasının olmadığı ispat edilse dahi, yöneticilerin ısrarlı görevlendirme taleplerini kesin şekilde reddederken işkenceyi, hatta ölümü göze aldığı, en azından sivil itaatsizlik tavrını benimsediği inkar edilemez. Bu açıdan onun isyanları desteklemediği görüşü, kanaatimizce, teori-pratik farklılığını izah etmede yetersiz kalmaktadır. Bu farkııı̆ın özellikle diğer mezheplerle mukayese edildiğinde Hanefiler'in yaklaşımını en uç noktaya yerleştirmesi meselenin izahını daha da zorlaştırmaktadır.

Konunun teorik boyutu farklı bir bakışla yeniden ele alınabilir mi? Bu bağlamda, Cessâs'ın (ö. 370) fasık kişilerin hakim ve yöneticiliği hususunda Ebu Hanife'nin farklı yaklaşım sergilediğini iddia edenlerin yanıldığını vurgulaması önemlidir. Cessâs, Ebu Hanife'nin yargı göreviyle devlet başkanlığını farklı değerlendirdiği, fasık yöneticiyi onayladığını ileri sürenlerin yanılgı içinde olduklarını, Ebu Hanife'nin her iki vazife için de adaleti şart koştuğunu belirtmiştir. ${ }^{72}$ Oysa Hanefî mezhebinde benimsenen görüş, fasık hakimin kararlarının geçerli oluşudur. ${ }^{73}$ İbnü'l-Hümâm, Hanefî mezhebinin üç imamının fasık şahsın yargı görevini icra etmesini caiz görmediğini belirtmiştir. Daha sonra o, Gazzâlî́nin (ö. 505) "sonraki asırlarda içtihat ve adalet şartını sağlayan şahısların bulunmasının zor olduğu gerekçesiyle devlet başkanının atadığı her hakimin görevinin geçerli sayılması gerektiğine" dair görüşünü aktararak Hanefî mezhebinin yaklaşımının da bu yönde olduğunu ileri sürmüştür. ${ }^{74}$

Fasık kişinin yargı görevine getirilmesi Ebu Hanife tarafından kabul edilmemesine rağmen, sonraki dönemlerde Hanefî hukukçuların aksi görüş benimsemesi, 
Hanefî eserlerde isyan suçunda Ebu Hanife'nin yaklaşımından farklı hükümlere yer verilmesiyle benzerlik arz etmektedir. Bu bağlamda, devlet idaresiyle ilgili konularda onun görüşlerinin arka planda kalma, İmâmeyn veya diğer hukukçuların görüşlerinin ön plana çıkması muhtemel gözükmektedir. Bununla birlikte, Hanefî metinlerde devlet başkanına diğer mezheplere kıyasla daha ziyade yetkilerin tanındığı birçok meselede Ebu Hanife'nin farklı yaklaşım sergilediğine (başvurduğumuz eserlerde) yer verilmemekte, bazı konularda ise ilgili görüş doğrudan Ebu Hanife'ye izafe edilmektedir. Örneğin Serahsî had suçlarında devlet başkanına ceza tatbik edilmeyeceği hükmünü Ebu Hanife'nin görüşü olarak aktarmaktadır. ${ }^{75}$ Ayrıca Ebu Hanife'ye göre, devlet başkanı izin vermedikçe ölü araziyi ihya eden kişinin ona sahip olamayacağı; İmâmeyn'nin ise bu izni gerekli görmediği belirtilmektedir. ${ }^{76}$ Benzer şekilde, mahkeme kararının haramı helal kıldığını, hakimin hükmünün diyâneten ve kazâen geçerli olduğunu hukukçuların içinde sadece Ebu Hanife ileri sürmektedir. ${ }^{77}$

Ebu Hanife'nin görüşleri incelendiğinde yönetimin hakimiyetini ön planda tuttuğu, devlet başkanına önemli hak ve yetkiler tanıdığı, hadlerin tatbik edilmemesi gibi örneklerde idareci için bazı ayrıcalıklar benimsediği, devletin önemli bir fonksiyonu olan yargı kararını haramı helal kılacak derecede önemsediği açıkça görülmektedir. Ebu Hanife gerçekten devlet başkanına yetkiler tanımada bazen en uç noktada yer almakta, daha dikkat çekici olan kamu görevi alan öğrencilerini bazı meselelerde geride bırakmaktadır. Bu bağlamda, Ebu Hanife'nin kamusal alandaki görüşlerinin Evzâî (ö. 157) ve İbn Ebî Leylâ gibi devlet görevlilerinin fetvalarına zıt bir konumda bulunduğu, halka daha doğru gelen ve toplumun benimsediği hükümler olduğu şeklindeki görüşş ${ }^{78}$ isabetli gözükmemektedir.

Burada şu soru gündeme gelmektedir: Ebu Hanife bu denli önemsediği kamu otoritesinin ve hukuk sisteminin neden bir parçası olmaktan şiddetle uzak durmuştur? Yargı kararına diğer hukukçulara kıyasla farklı bir önem atfeden Ebu Hanife'nin İbn Ebî Leylâ'nın mahkeme kararlarını sorgulaması dikkat çekici bir husustur. Zira toplumdaki itibarı göz önüne alındığında talebelerine sorgulattığı kararlarla Ebu Hanife, devletin hukuki otoritesini önemli oranda sarsmış oluyordu. Ebu Hanife'nin bunun farkına varmaması imkan dahilinde değildir. 
Ebu Hanife'nin yönetimin gücünün farkında olduğu ve teorik açıdan birtakım hükümlere vardığı, pratikte idareye karşı tavrının bundan farklı düşünülmesi gerektiği ileri sürülebilir. Ancak onun bir taraftan yönetimlere karşı son derece mesafeli, hatta onları yok sayan tavrıyla diğer hukukçulara nispetle yöneticilere daha ziyade yetkiler tanıyan görüşlerini uzlaştırma, kanaatimizce o derece imkansızdır ki, teori-pratik bütünlüğü sadece Hanefi fıkhında yönetimle ilgili meselelerde Şafii ve Hanbeli mezhebiyle benzer görüşlerin varlığı halinde mümkün olabilir. Oysa Hanefi mezhebi bu gibi konularda ilgili mezheplerin karşısında yer almakta, anlaşıldığı kadarıyla Ebu Hanife de tavır ve eylemleriyle İmameyn'den farklı bir konumda bulunmaktadır.

\section{Sonuç}

Hukuki meselelerde hükme varırken nasları zahirî yaklaşımla ele almakla kamu yararını gözeterek incelemek arasında önemli farklar bulunduğu söylenebilir. Kamu yararının gözetilmesinde devlet yönetiminde tecrübe kazanmanın, kamu görevi icra etmenin etkili olduğu kanaatindeyiz. Günümüzde siyasi partilerin iktidara geldiklerinde muhalefetteki söylemlerinden farklı icraatlarda bulunması, bir açıdan, parti mensuplarının devlet yönetiminin çok yönlü olduğunu fark etmeleriyle ilişkilidir, denilebilir. Nitekim siyasetle iç içe olan İbn Sina'nın (ö. 428) felsefesinde devlet yönetimi, politika önemli yer kaplamazken; devlet yönetiminden uzak duran Farâbî'nin (ö. 339) felsefesinin merkezine siyaseti koyması bu bağlamda değerlendirilebilir. Yani İbn Sina filozofların zihnine öncelikle gelen birtakım ideal kuralların devlet yönetiminde etkili olamayacağını tecrübe etmiş;; Farabî ise bu tecrübeden yoksun kaldığı için tarih boyunca hiç gerçekleşmemiş devlet ve toplum yönetimini, yani ideal olanı resmetmiştir, diyebiliriz.

Kamu görevlilerinin mensubu olduğu devletin icraatlarını savunması, desteklemesi muhtemeldir. Nitekim Şeyhülislam Ebussuud Efendi'nin (ö. 982) para vakıflarını savunması bu bağlamda değerlendirilebilir. Belirtmek gerekir ki, Ebussuud Efendi'nin sadece devlette önemli görevde bulunduğu için devletin icraatlarını, pratiği savunduğunu ileri sürmek isabetli gözükmemektedir. Zira yöneticilerden devletin devamlılığını, kamu nizamını sağlamak için birtakım vasıtalardan yararlanması, farklı koşulları dikkate alması, yeni çözümleri zamanın şartlarına göre üretmesi beklenir. Aksi takdirde devletin canlılığı, hayatiyeti sona erer.

Bu bağlamda, yargı görevini üslenen kadıların öncelikle kamu nizamını, yani devletin bekasını düşünmeleri, yaşadıkları tarihi ve siyasi tecrübelerle örneğin isyan 
suçuyla ilgili meselelerde öncelikle yönetimin yani devletin çıkarlarını düşünerek (bu genelde kamu yararından bağımsız değerlendirilemez) isyancılara yönelik daha sert tavır almaları beklenirken; devlet yönetimiyle ilişkisi olmayan hukukçuların daha idealist yaklaşım sergileyerek isyancıların çıkarlarını da gözeten yaklaşımlar benimsemesi mümkündür. Nitekim Hanefîler'in isyancılara karşı daha katı kurallar benimsemesi, Hanefi mezhebinin devletlere resmi mezhep olması, İmâmeyn'nin kadılkudatlık görevlerini icra etmeleri, sonraki Hanefî hukukçuların kadılık görevlerine getirilmeleriyle paralellik arz etmektedir. İsyan suçunda ve devlet başkanına bazı hususlarda daha ziyade yetkiler tanımada onları Malikiler'in takip etmesi, Malikî mezhebinin Kuzey Afrika ve Endülüs'te hakim mezhep olması ve bu bölgelerde kadıların ilgili mezhebe mensup hukukçulardan atanmasıyla ilişkili gözükmektedir. Şâfiî ve Hanbelî mezhebinin isyan suçunda isyancılara yönelik daha hoşgörülü kurallar benimsemesi ve devlet başkanına makalede incelenen meselelerde diğer iki mezhebe kıyasla daha az yetki tanıması, onların devletlerle ilişkisinin diğer iki hukuk ekolü derecesinde olmamasıyla uyumludur.

Kamu görevi alan, devlet tecrübesinden yararlanan şahısların kamu yararını daha ön planda tutarak realist yaklaşım; kamu görevinden uzak duranların nispeten idealist tutum sergilediklerine dair görüş, Ebu Hanife söz konusu olduğunda farklı bir mahiyet arz etmektedir. Aslında isyan suçunda Ebu Hanife'nin diğer Hanefî hukukçulardan farklı görüşlere sahip olduğuna yer verilmiştir. Bununla birlikte, devlet başkanının hak ve yetkileriyle ilgili birçok meselede, Hanefî hukukçular, diğer mezheplerle kıyaslandığında devlet başkanına daha ziyade yetkiler tanırken Ebu Hanife'nin ilgili konularda isyan suçunda olduğu gibi farklı bir yaklaşım sergilediğine temas edilmemiştir. Ayrıca devlet başkanına had tatbik edilmeyeceği görüşü, Hanefî metinlerde doğrudan ona isnat edilmiştir. Bunun yanında diğer bütün hukukçulardan farklı olarak hakimin kararının haramı helal kıldığını, yani diyaneten de geçerli olduğunu savunan Ebu Hanife, yargı kararına, dolayısıyla kamu otoritesine büyük önem atfetmiştir.

Bu bağlamda, kamu idaresine önemli yetki ve ayrıcalıklar tanıyan, yargı kararının haramı helal kılacak mahiyette olduğunu savunan Ebu Hanife'nin kamu görevi almak ve hukuk sisteminin bir parçası olmaktan neden uzak durduğu sorusu gündeme gelmektedir. İlgili teori-pratik uyuşmazlığını izah etmek, ileri düzey araştırmalara ihtiyaç doğurmaktadır. Onunla ilgili bazı tarihi bilgilerin sıhhatinin yeniden ele alınması veya onun iktidarlara yönelik tavrındaki asıl saikin ne olduğunun belirlenmesinin ilgili hususun aydınlatılmasında yardımcı olacağı kanaatindeyiz. 


\section{Kaynakça}

Aydın, Ahmet. "Dört Mezhep İmamının Otoritesini Tesis Eden Temel Unsurlar -Güven-Otorite Iliş̧kisine Dair Bir Analiz-". Türkiye Din Eğitimi Araştırmaları Dergisi, 4 (2017): 77-88.

Aydın, Ahmet “Hz. Ömer'in Uygulamalarını Devlet Başkanının Tasarruf Yetkisi Bağlamında Değerlendirmek." II. Uluslararası Multidisipliner Çalışmalar Sempozyumu Tam Metin Bildiriler Kitabı Sosyal Bilimler içinde. Bu bildiri 16-17 Kasım 2018 tarihleri arasında II. Uluslararası Multidisipliner Çalışmalar Sempozyumu'nda sunulmuştur. Ankara: Berikan Matbaacılık, 2018: 19-32.

Bardakoğlu, Ali, “Hanefì Mezhebi”, DiA. XVI, 4. İstanbul: Diyanet Vakfı Yayınları, 1997.

Beyhakî, Ebû Bekr Ahmed b. el-Hüseyin b. Ali. Ma'rifetü's-sünen ve'l-âsâr. Kâhire: Dâru'I-Vefâ, 1991.

Buhârî, Ebû Abdullah Muhammed b. İsmâîl. el-Câmi'us-Sahîh. İstanbul: Dârü't-Tıbâati'l-Âmire, 1315.

Buhûtî, Şeyh Mansûr b. Yûnus b. Selâhiddîn. Keşşâfü'I-Kınâ' an metni'I-Iknâ'. Beyrut: Dâru'I-Fikr, 1982.

Buhûtî, Şeyh Mansûr b. Yûnus b. Selâhiddîn. Şerhu Müntehel-irâdât. Beyrut: Âlemü'l-Kütüb, 1996.

Cessâs, Ebû Bekir Ahmed b. Ali er-Râzî. Ahkâmu'I-Kur'an. Beyrut: Dâru'l-Fikr, t.y.

Çetintaş, Recep. "Hanefiler'in Cuma Namazını Devlet Başkanı veya İzin Verdiği Kimselerin Kıldırması Şartıyla Kayıtlamasına Usûlî Bir Bakış." Cumhuriyet Üniversitesi Illahiyat Fakültesi Dergisi, 18/2 (2014): 207-240.

Derdîr, Ebu'l-Berekât Ahmed b. Muhammed Adevî. eş-Şerhu'l-kebîr alâ Muhtasarı Halîl. Beyrut: Dâru'l-Fikr, t.y.

Desûkî, Ebû Abdullah Şemseddîn Muhammed b. Ahmed. Hâşiyetü'd-Desûkî alâ Şerhi'l-kebîr. Beyrut: Dâru'l-Fikr, t.y.

Doğan, İsa. "Ebû Hanîfe'nin Dînî ve Siyâsî Duruşu". Ondokuz Mayıs Üniversitesi Illahiyat Fakültesi Dergisi, 22 (2006): 37-47.

Ebû Dâvûd, Süleymân b. Eş'as b. İshâk. Kitâbü's-Sünen, thk. Muhammed Avvâme. Cidde: Dârü'l-Kıble li's-Sekâfeti'l- İslâmiyye, 1998.

Ensârî, Zekeriyyâ b. Muhammed b. Ahmed. Esne'l-metâlib şerhu Ravzi't-tâlib. Beyrut, Dâru'l-Kütübi'l-IIlmiyye, 2000.

Erkal, Mehmet. "Ganimet." DIA. XIII, 351-354. İstanbul: Diyanet Vakfı Yayınları, 1996.

Gazzali, Ebû Hamid Huccetülislam Muhammed b. Muhammed. el-Vasît fi'l-mezheb. Kâhire: Dâru'I-İslam, 1417.

Haraşî, Ebû Abdullah Muhammed b. Abdullah. Şerh alâ muhtasarı Hâlîl. Beyrut: Dâru'l-Fikr, t.y.

İbnü'I-Hümâm, Kemâleddîn Muhammed b. Abdülvâhid. Şerhu Fethi'I-kadîr.(Mısır, Matbaatu Mustafâ el-Bâbî el-Halebî, 1970.

İbn Kudâme, Muvaffakuddîn Abdullah b. Ahmed. el-Muğni. Beyrut: Dâru Ihyâi't-Türâsi'I-Arabî, t.y.

İbn Rüş̧ (Ced), Ebu'l-Velîd Muhammed b. Ahmed. el-Beyân ve't-tahsîl, thk. Muhammed Haccî. Beyrut: Dâru'I-Garbi'I-İslâmî, 1998.

İbn Rüşd (Hafîd), Ebu'l Velîd Muhammed b. Ahmed. Bidâyetül-müctehid ve nihâyetül-muktesıd. Mısır: Matbaatü Mustafa el-Bâbî el-Halebî ve Evlâdühû, 1975.

İbn Sa'd, Ebu Abdullah. et-Tabakâtü'l-kübrâ. Beyrut: Dâru Sadır, 1968.

Iliş̧, Muhammed b. Ahmed b. Muhammed. Minehu'l-celîl alâ muhtasarı Halil. Beyrut: Dâru'l-Fikr 1989. 
Karâfî, Şehâbeddîn Ahmed b. İdrîs. Zehîra. Beyrût: Dâru'l-Garbi'I-Islâmî, 1994.

Kâsânî, Ebû Bekr b. Mes'ûd b. Ahmed. Bedâi'us-sanâi' fî tertîbi'ş-şerâi'. Beyrût: Dâru'l-Kitâbi'l-Arabî, 1982.

Mâverdî, Ebü'I-Hasan Ali b. Muhammed. el-Hâvi'I-kebîr fî fıkhi'ş-Şâfiî. Beyrut: Dâru'I-Kütübi'I-IImiyye, 1994.

Merdâvî, Alâeddîn Ali b. Süleymân. el-Insâffî ma'rifeti'r-râcih mine'l-hilâf alâ mezhebi'l-imâmi'l-mübeccel Ahmed b. Hanbel. Beyrut: Dâru Ihyâi't-Türâsi'l-Arabî, 1986.

Mergînânî, Burhâneddîn Ali b. Ebî Bekr. el-Hidâye Şerhu Bidâyeti'l-mübtedî. İstanbul: Kahraman Yayınları, 1986.

Nevevî, Yahyâ b. Şeref. el-Mecmû' Şerhu'I-Mühezzeb. Kâhire: el-Matbaatü'I-Mûniriyye, t.y.

Ruhaybânî, Mustafa es-Suyûtî. Metâlibü üli'n-nühâ fi şerhi Gâyeti'l-müntehâ. Dımaşk: el-Mektebü'l-Islâmî, 1961.

Serahsî, Şemsü'l-Eimme Muhammed b. Ahmed b. Sehl. el-Mebsût. Kâhire: Matbaatu's-Sa'âde, 13241331.

Şirbînî, Şemseddîn Hatîb Muhammed b. Ahmed. Mugni'l-muhtâc ilâ ma'rifeti meânî elfâzi'l-Minhâc. Beyrut: Dâru'l-Fikr, t.y.

Tutar, Adem. “Ebu Hanife'nin Din-Siyaset İlişkisi Açısından Konumu." IV. Uluslararası Şeyh Şa'bân-ı Velî Sempozyumu -Hanefilik-Mâturîdîlik-05-07 Mayıs 2017, 2 (2017): 585-593.

Udeh, Abdülkâdir. et-Teşrîu'I-cinâiyyü'l-Isłlâmî: Mukârenen li-kânûni'I-vaz'î. Kâhire: Dâru't-Türâs, 1977.

Uzunpostalcı, Mustafa. “Ebu Hanife”, DiA. İstanbul: Diyanet Vakfı Yayınları, 1994.

Yaman, Ahmet. "Siyaset-Hukuk Iliş̧isi Bağlamında Ebu Hanife Dönemi.", İslami Araştırmalar, 15/1-2 (2002): 273-281.

Yaman, Ahmet. "Seleb". DIA. XXXVI, 398-399. İstanbul: Diyanet Vakfı Yayınları, 2009.

Zeylaî, Fahreddin Osman b. Ali b. Mihcen. Tebyînu'l-hakâyık şerhu Kenzi'd-dekâik. Bulak: Matbaatu'l-Kübra'l-Emîriyye, 1314. 
